\title{
Seasonal variations of downward particle fluxes in front of a reef pass (Moorea Island, French Polynesia)
}

\section{Variations saisonnières des flux particulaires en face d'une passe lagonaire (Morea, Polynésie française)}

\author{
Muriel Schrimm a,b, Serge Heussner ${ }^{\mathrm{a}, *}$, Roselyne Buscail ${ }^{\mathrm{a}}$ \\ ${ }^{a}$ Centre de formation et de recherche sur l'environnement marin, CNRS UMR 5110, université de Perpignan, \\ 52, avenue de Villeneuve, 66860 Perpignan cedex, France \\ ${ }^{\mathrm{b}}$ Centre de recherches insulaires et observatoire de l'environnement, BP 1013 Moorea, Polynésie française \\ et Laboratoire de biologie marine et malacologie, École pratique des hautes études, université de Perpignan, \\ 52, avenue de Villeneuve, 66860 Perpignan cedex, France
}

Received 24 August 2001; received in revised form 6 December 2001; accepted 6 December 2001

\begin{abstract}
Downward particle fluxes off the Taotoi Pass, a typical Polynesian lagoon pass, have been measured over an annual cycle by means of an array of three mooring lines deployed at $40 \mathrm{~m}$ depth on the external sandy plain seawards of the Tiahura reef. Each line was equipped with two hand-operated sediment traps located 1.5 and $10 \mathrm{~m}$ above the bottom. During the 1-year survey, the traps were deployed for seven periods of 2-3 weeks. One line equipped with an automated trap was further deployed at $400 \mathrm{~m}$ depth on the deep fore-reef slope to collect deep settling particles over two consecutive 6-month periods. For all periods investigated, fluxes on the external plain were highest in front of the pass, and decreased by half on either side (up- and downstream with respect to general circulation), indicating a net export through the pass. At all three locations, the highest downward fluxes recorded (60-100 $\mathrm{g} \mathrm{m}^{-2} \mathrm{~d}^{-1}$ ) corresponded to coarse particles mostly carbonate, whereas the lower fluxes (a few $\mathrm{g} \mathrm{m}^{-2} \mathrm{~d}^{-1}$ ) corresponded to smaller and lighter material mostly organic carbon. Fluxes on the deep slope were much lower than on the sandy plain $\left(1.5-7.3 \mathrm{~g} \mathrm{~m}^{-2} \mathrm{~d}^{-1}\right)$, but followed a broadly similar seasonal trend. Comparison of our trap data with published production values for the Tiahura reef system suggests that inorganic and organic carbon export through the pass is limited. The minimum estimates represent around $6 \%$ of total calcification but only $1 \%$ of the net production of the reef system. The qualitative and quantitative temporal evolution of downward fluxes showed a seasonally-contrasted trend, related to local hydrodynamic conditions. Fluxes were always higher during the southern summer season, and lower during winter. Carbon export appears to be ultimately controlled by climatic factors, i.e. seasonal changes in the orientation and heights of swells and waves that modulate the amount of water flowing into the lagoon, before being flushed out into the open ocean, entraining particles. (C) 2002 Ifremer/CNRS/IRD/Éditions scientifiques et médicales Elsevier SAS. All rights reserved.
\end{abstract}

\section{Résumé}

Les flux particulaires ont été mesurés devant la passe lagonaire de Taotoï (côte Nord de Moorea, Polynésie française) sur une période annuelle, au moyen de trois lignes de mouillage de pièges à particules déployées à $40 \mathrm{~m}$ de profondeur sur la plaine sableuse située à l'extérieur du récif barrière de Tiahura. Chaque ligne comporte deux pièges à particules manuels situés à $1,5 \mathrm{~m}$ et $10 \mathrm{~m}$ au-dessus du fond. Ces pièges ont été déployés durant sept périodes de deux à trois semaines. Un piège à particules automatique a, en outre, été déployé à $400 \mathrm{~m}$ de profondeur sur le tombant afin de collecter, de façon séquentielle, des échantillons mensuels de particules pendant deux périodes consécutives de six mois. Les flux mesurés sur la plaine sableuse sont toujours plus élevés devant la passe. Ils diminuent de moitié environ pour les stations placées en «amont » et en «aval » de la passe (en référence au courant de dérive générale à l'extérieur du récif barrière),

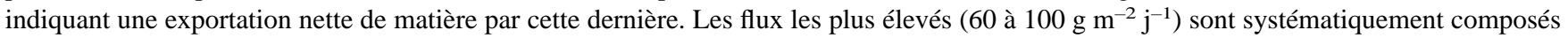

\footnotetext{
* Corresponding author.

E-mail address: heussner@univ-perp.fr (S. Heussner).
} 
de particules lourdes et carbonatées. À l'inverse, les flux les plus faibles (quelques $\mathrm{g} \mathrm{m}^{-2} \mathrm{j}^{-1}$ ) se composent d'un matériel plus fin, plus léger,

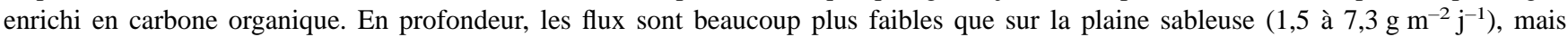
présentent un signal saisonnier similaire. La comparaison de nos résultats avec les valeurs de production publiées pour le système récifal de Tiahura suggère que l'exportation de carbone inorganique et organique par le récif reste un phénomène limité, avec des minima d'environ $6 \%$ de la calcification totale et de $1 \%$ de la production nette. L'évolution temporelle des flux présente une tendance saisonnière marquée, liée à la variation des conditions hydrodynamiques locales: les flux sont toujours plus élevés en période d'été austral et plus faibles en hiver. L'exportation de carbone semble ainsi contrôlée par les facteurs climatiques, c'est-à-dire les changements saisonniers d'orientation des houles et des vagues qui modulent les arrivées d'eau dans le lagon et donc le transport particulaire associé au flux d'eau sortant. (C) 2002 Ifremer/CNRS/IRD/Éditions scientifiques et médicales Elsevier SAS. Tous droits réservés.

Keywords: Particle flux; Carbon export; Coral reefs; Organic carbon; Carbonate

Mots clés: Flux particulaire; Exportation de carbone; Récif corallien; Carbone organique; Carbonate

\section{Introduction}

Since the pioneering work of Sargent and_Austin (1949) and Odum and Odum (1955) coral reefs have been considered as productive ecosystems in oligotrophic environments, especially for those located far away from continents. To solve the so-called 'nutritional paradox', numerous studies focused on reef systems with the aim of understanding their functioning Kinsey 1985. Crossland et al. 1991: Pichon, 1996 and their interaction with the surrounding environment CAndrews and Gentien 1982. Rougerie and Wauthy, 1986. Pichon, 1997: Basillais, 1998 have been carried out. Studies were conducted at various time and space scales, either to draw up trophic budgets Hatcher et al. 1987; Arias-Gonzalez. 1994) or to quantify energy flows through the reef system Sournia. 1977. Hatcher_1990. Special attention was paid to inputs of organic and inorganic carbon to the system and to their living/non-living nature. On the contrary, direct quantification of carbon outputs has seldom been performed. Regarding these outputs, three different routes can be considered: (i) 'geological fossilisation', which represents the organic or inorganic carbon trapped in the reef frame (e.g. Hubbard et al, 1990) (ii) carbon loss by release of carbon dioxide from the reef waters to the atmosphere (e.g. Gattuso et_al 1996a) and (iii) carbon export from the reef system to the open ocean. The importance of this third route has been either deduced from carbon and carbonate budgets SSmith and Jokiel. 1978: Smith et al. 1978: Taguchi. 1982: Atkinson and Grigg. 1984 or directly measured on particulate and dissolved matter in reef waters Q Qasim and Sankaranarayanan, 1970; Sabine and MacKenzie, 1995; Hata et al. 1998). On the whole, direct measurements of carbon export have been essentially based on limited surveys, and remain therefore poorly documented.

Following a short multidisciplinary study in the same area performed within the Emir experiment Delesalle et al. 1998) the present work has been designed to estimate the seasonal variability of downward particle fluxes on the external sandy plain off a major reef pass of Moorea, French Polynesia, with the final aim of estimating particulate carbon export through the pass and identifying the organic or inorganic nature of the exported material. To do so, downward particle fluxes were measured at several locations by an array of sediment traps deployed over an annual cycle in front and on either side of the pass.

\section{Materials and methods}

\subsection{Study site and sampling strategy}

The study was conducted in the vicinity of the Taotoi Pass, on the NW coast of Moorea (17 $30^{\prime} \mathrm{S}, 149^{\circ} 50^{\prime} \mathrm{W}$ ) in French Polynesia (Fig. 1). Moorea is a high volcanic island fringed by a reef system. The outer reef is interrupted by several passes through which lagoon waters are flushed out. The Taotoi pass essentially drains turbid waters from the 6- $\mathrm{km}^{2}$ Tiahura lagoon (Lenhardt, 1988). The resulting plume is generally deflected westward by the general circulation of oceanic water masses.

Three mooring lines were deployed outside the pass from November 1995 to November 1996 on the sandy plain, a $150-\mathrm{m}$ wide gently sloping platform extending from the base of the reef front (around 25-30 $\mathrm{m}$ in depth) down to the vertical drop-off (around $70 \mathrm{~m}$ in depth). The lines were located at a distance of $250 \mathrm{~m}$ from the reef front and at a depth of $40 \mathrm{~m}$, one in front of the pass and the other two $700 \mathrm{~m}$ east and west of the pass. Thus, with respect to the general westward oceanic circulation, the eastern line was located upstream of the pass, and the western line downstream. Each line was equipped with two multitube traps deployed at 1.5 and $10 \mathrm{~m}$ above bottom (hereafter m.a.b.) and sufficient floatation to ensure a taut, upright position. Each trap was composed of four unbaffled tubes, $40 \mathrm{~cm}$ in height and $10 \mathrm{~cm}$ in diameter, i.e. with an aspect ratio (height/diameter) of four. The capped tubes were attached in position by scuba diving, opened and left to collect settling particles for periods of 2-3 weeks every 2 months.

For the deeper environment, particles were collected with an automated PPS3 trap (Heussner et al. 1990) This unbaffled, cylindroconical trap, $2 \mathrm{~m}$ in height and $40 \mathrm{~cm}$ in 


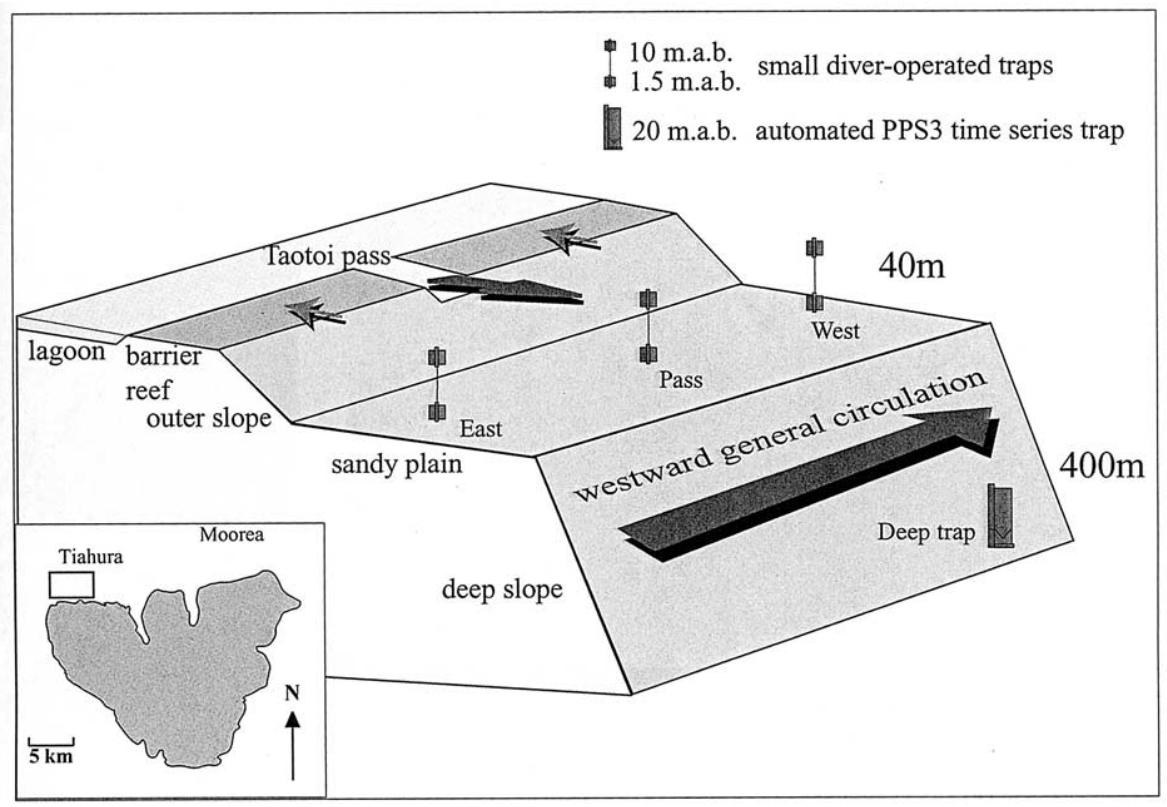

Fig. 1. Location of the sampling stations on the north-western coast of the island of Moorea, French Polynesia.

diameter, is fitted with six receiving cups, and has an aspect ratio of 2.5 for the cylindrical part. It was deployed at $400 \mathrm{~m}$ in depth on the outer slope (20 m.a.b.), at a distance of $900 \mathrm{~m}$ from the reef straight off the western small trap site. The trap was deployed for two consecutive 6-month periods to collect sequential samples at monthly intervals.

\subsection{Trap sample treatment}

Before deployment, traps were poisoned to prevent the degradation of settling particles and to avoid the physical disruption and chemical alteration of swimming organisms entering the traps during sample collection. Two different methods were used since the two trap designs were not handled in the same way. To avoid flushing of the poisoning solution from the small traps during their deployment, a concentrated formalin solution $(10 \% \mathrm{v} / \mathrm{v})$ in $0.45-\mu \mathrm{m}$ filtered brine $\left(200 \mathrm{~g} \mathrm{l}^{-1}\right)$ and buffered at $\mathrm{pH} 7.8$ with analytical sodium tetraborate was introduced into a small glass vial that was placed on the bottom of each tube. The poisoning solution slowly diffused during the collection period through small holes in the vial cap. For the automated PPS 3 trap, the receiving cups were filled with a $5 \%$ formalin solution in $0.45-\mu \mathrm{m}$ filtered seawater buffered at $\mathrm{pH} 7.8$.

After recovery, the collected particles were decanted, and formalin was added if necessary. Samples were stored at $2-4{ }^{\circ} \mathrm{C}$ in the dark before processing in the laboratory. Samples were treated following a two-step procedure. First, they were wet-sieved through a 1-mm nylon mesh, in order to remove the largest swimmers (i.e. large copepods, mysiids and euphausiids) and the marine and higher plant debris $>1 \mathrm{~mm}$. The remaining $<1-\mathrm{mm}$ sample was divided into two aliquots. One aliquot was preserved as a wet record, whereas the second was split into a heavy and a light fraction using a 1-m settling column that allows recovery of settling particles through a bottom tap. Owing to the relatively coarse size of collected particles, the limit between the two fractions was set at a settling velocity of $500 \mathrm{~m} \mathrm{~d}^{-1}$. Both fractions were then sorted under a dissecting microscope to remove the $<1-\mathrm{mm}$ swimmers (i.e. small copepods, pteropods, ostracods and annelids). They were rinsed with distilled water to remove salts, freeze-dried, and accurately weighed to determine the total mass collected. The reproducibility of mass flux measurements by the small traps was determined by analysing all four tubes from three different trap samples at the beginning of the experiment. The coefficient of variation $(\mathrm{CV} \%)$ of dry weights varied between 1.3 and $3.4 \%$. Since the inter-tube variability was very low, it was decided to process only one tube per trap deployment for the remaining experiment to save time. Standard deviation of the determination of heavy and light fractions within four tubes from a given deployment ranged between 0.2 and $2.9 \%$.

Total carbon and organic carbon (after treatment with $2 \mathrm{~N}$ $\mathrm{HCl})$ contents for each weight fraction and each sample were determined on 30-mg ground subsamples by combustion in a Leco CS-125 analyser, using the method described by Cauwet (1975. The reproducibility of carbon determination $(\mathrm{CV} \%)$ between the four tubes from a same sample was $<1 \%$ for total carbon and around $6 \%$ for organic carbon.

Mean fluxes for each trap (expressed in $\mathrm{g} \mathrm{m}^{-2} \mathrm{~d}^{-1}$ ) were obtained by weighting individual values by the duration of the corresponding sampling period and are expressed as time-weighted means. The average content of any specific component (expressed as a weight percentage) is given as a time- and flux-weighted mean (Biscaye et al. 1988; Heussher et al_ 1999. This way of presenting means produces 
East

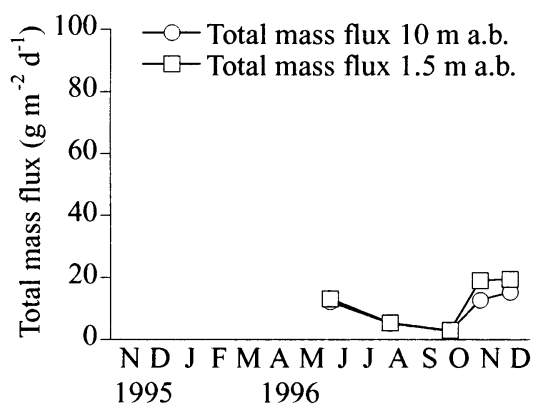

Pass

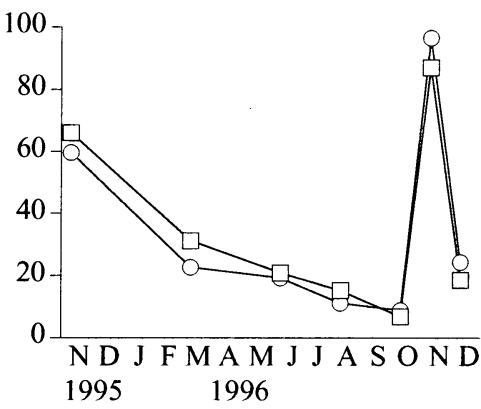

West

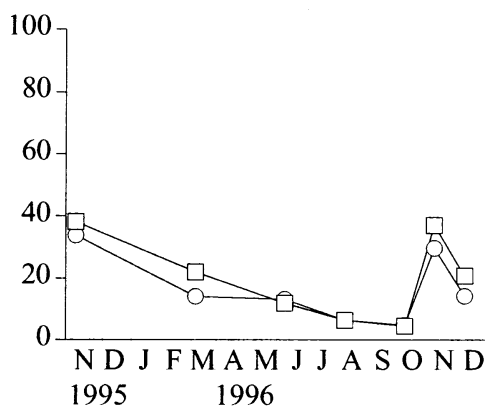

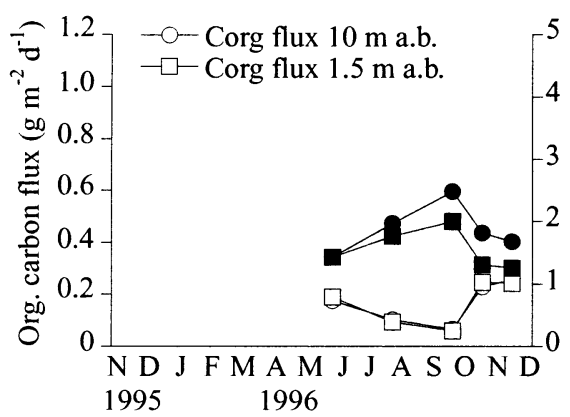
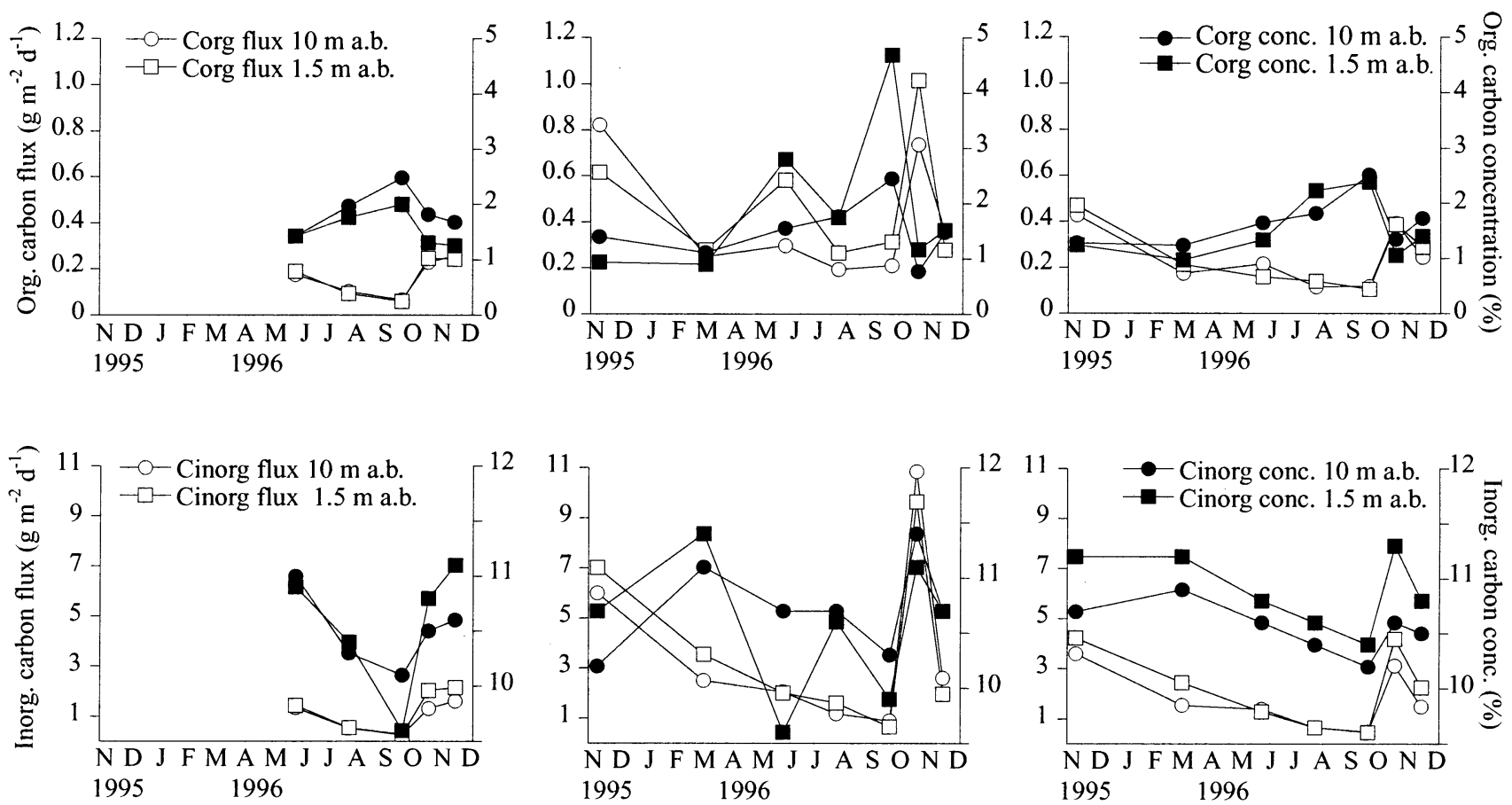

Fig. 2. Spatial and temporal variations of total mass flux $\left(\mathrm{g} \mathrm{m}^{-2} \mathrm{~d}^{-1}\right)$, organic and inorganic carbon fluxes $\left(\mathrm{g} \mathrm{m}^{-2} \mathrm{~d}^{-1}\right)$ and concentrations (weight $\left.\%\right)$ for the three trap stations on the sandy plain at $40 \mathrm{~m}$ in depth. Samples were collected between November 1995 and December 1996.

results that are equivalent to those that would have been obtained if particulate matter had been collected as a single sample throughout the duration of the experiment.

\section{Results}

\subsection{Total mass flux}

Total mass fluxes at the three sandy plain stations ranged from 2 to $96 \mathrm{~g} \mathrm{~m}^{-2} \mathrm{~d}^{-1}$ (Fig. 2). No significant differences between the fluxes measured by the near bottom traps and those at $10 \mathrm{~m}$.a.b. were observed, indicating a relative homogeneity through the lower part of the 40-m water column at each station. The highest fluxes were always found at the station in front of the pass, and yielded an annual mean value of $32.2 \mathrm{~g} \mathrm{~m}^{-2} \mathrm{~d}^{-1}$ (value averaged for the two traps at 1.5 and 10 m.a.b.). Fluxes to the west of the pass (mean: $17.2 \mathrm{~g} \mathrm{~m}^{-2} \mathrm{~d}^{-1}$ ) were slightly higher than to the east (mean: $10.8 \mathrm{~g} \mathrm{~m}^{-2} \mathrm{~d}^{-1}$ ). Despite the absence of the first two samples at the eastern station, we can safely consider that the temporal signals recorded at the three sandy plain sites were similar. Two major peaks were observed, occurring in November of the two consecutive years. The lowest fluxes were always observed during the southern winter season.

At a depth of $400 \mathrm{~m}$ on the slope, total mass fluxes recorded by the large trap were ten times lower than those measured at $40 \mathrm{~m}$ in depth on the sandy plain (Fig. 3). Fluxes varied from 1.5 to $7.3 \mathrm{~g} \mathrm{~m}^{-2} \mathrm{~d}^{-1}$, with a mean annual value of $3.2 \mathrm{~g} \mathrm{~m}^{-2} \mathrm{~d}^{-1}$. However, the temporal variability was quite similar to that observed in the shallower traps, with higher fluxes in summer, and lower fluxes during winter. 

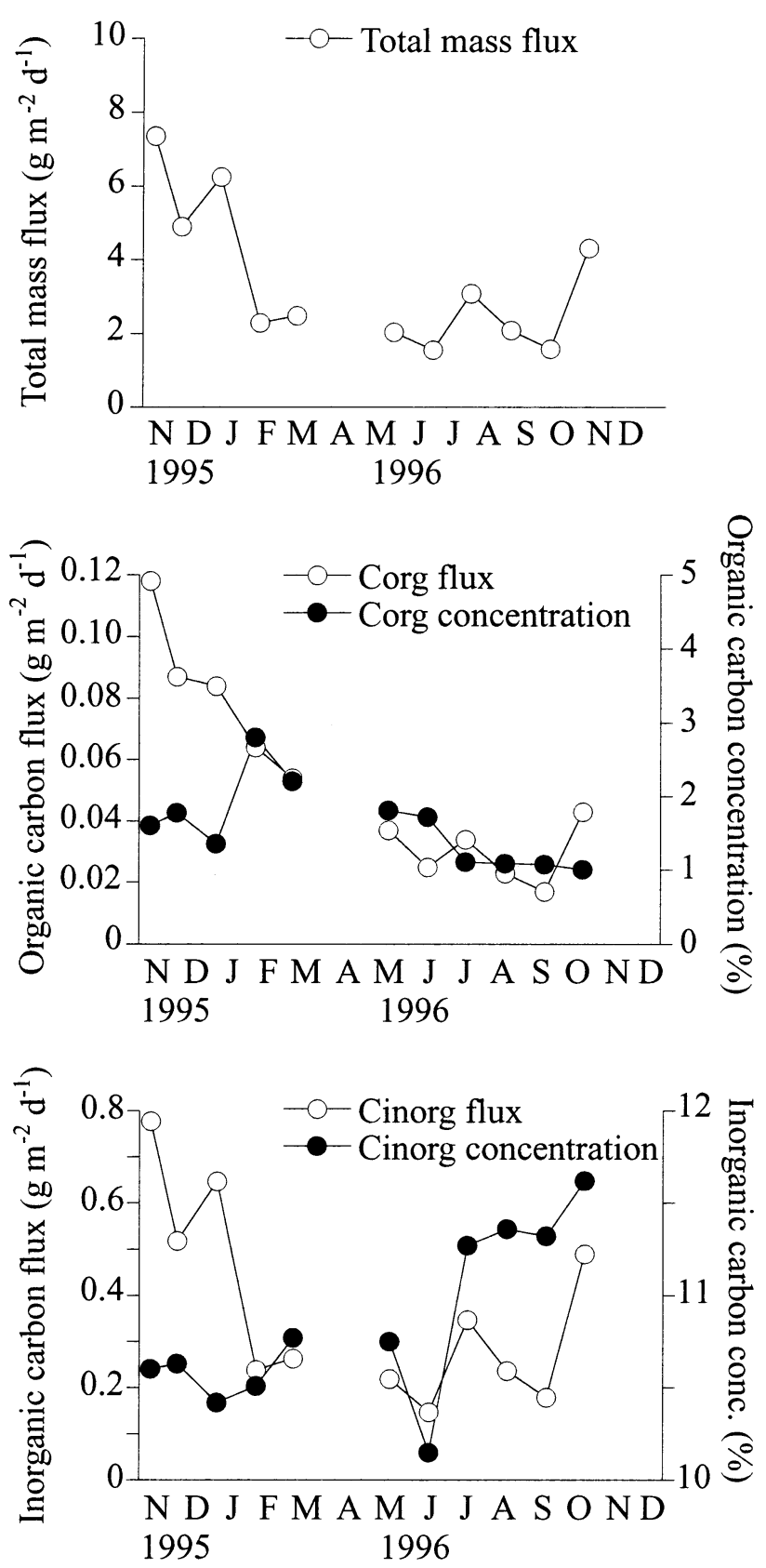

Fig. 3. Spatial and temporal variations of total mass flux $\left(\mathrm{g} \mathrm{m}^{-2} \mathrm{~d}^{-1}\right)$, organic and inorganic carbon fluxes $\left(\mathrm{g} \mathrm{m}^{-2} \mathrm{~d}^{-1}\right)$ and concentrations (weight $\%$ ) for the slope trap deployed at $400 \mathrm{~m}$ in depth. Samples were collected between November 1995 and December 1996 in two consecutive 6-month deployments of the trap.

\subsection{Biogeochemical composition of trapped particles}

Organic and inorganic carbon contents were quite similar for both traps (10 and 1.5 m.a.b.) of the three shallower stations (Fig. 2). They varied between 0.7 and $4.7 \%$ for organic carbon and between 9.6 and $11.5 \%$ for inorganic carbon. For the deep trap (Fig. 4), these contents were in the same range as for the shallower traps, but the amplitude of
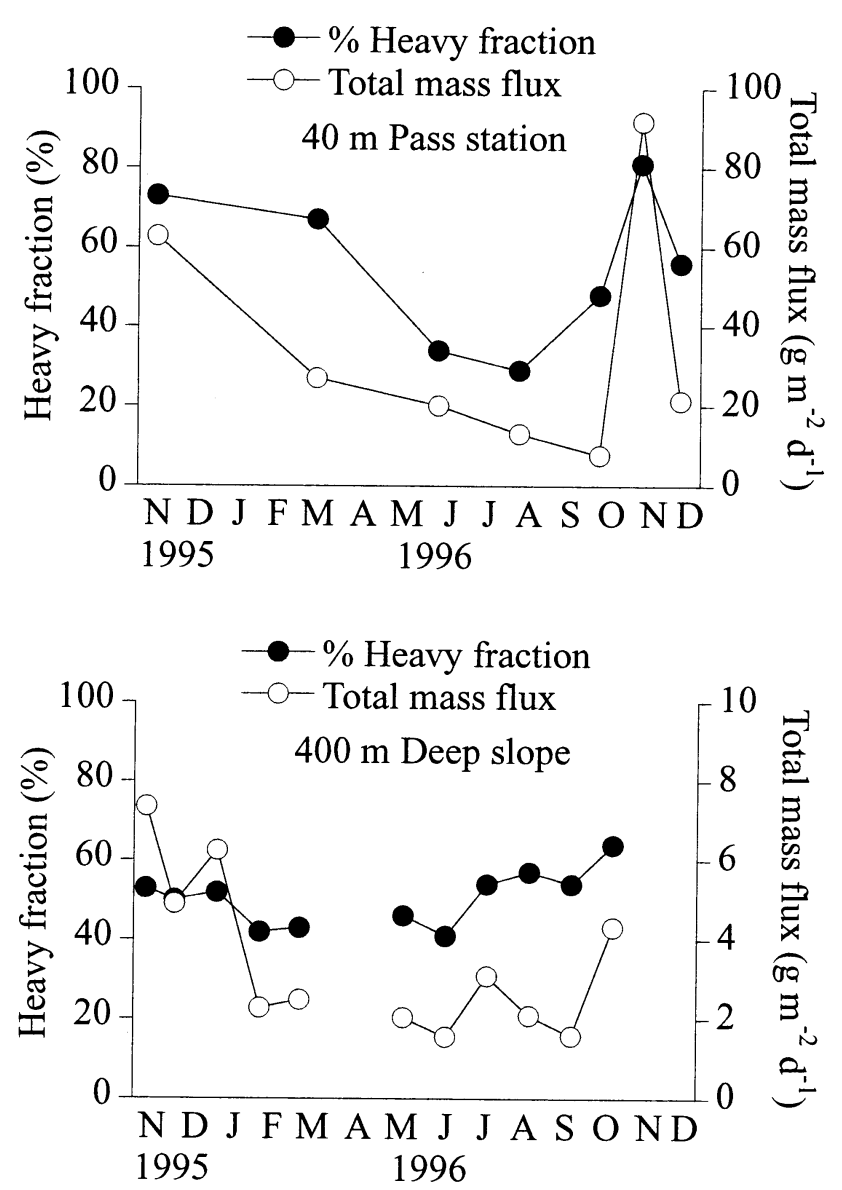

Fig. 4. Temporal trend in the proportion of the heavy fraction (particles with settling velocity $>500 \mathrm{~m} \mathrm{~d}^{-1}$ ) and total mass flux (light line) of settling particles collected at the Pass station on the sandy plain (40 $\mathrm{m}$ in depth) and on the slope (400 $\mathrm{m}$ in depth).

variation was lower. Organic carbon varied from 1 to $2.8 \%$, and inorganic carbon from 10.1 to $11.7 \%$.

Due to the relatively limited range of variation in organic and inorganic carbon contents (variation within a factor 5, at most) in comparison with the much higher variation in total mass fluxes (within a factor 10 to 20), variations in organic and inorganic carbon fluxes essentially matched those of total mass fluxes (Figs. 2 and 3). For the shallower traps, organic carbon fluxes ranged between 0.06 and $1.0 \mathrm{~g} \mathrm{~m}^{-2} \mathrm{~d}^{-1}$. Except for the pass station, organic carbon fluxes followed a temporal pattern opposite to that of organic carbon contents. Inorganic carbon fluxes ranged between 0.3 and $11 \mathrm{~g} \mathrm{~m}^{-2} \mathrm{~d}^{-1}$, following the same temporal pattern as inorganic carbon contents. Carbon fluxes recorded by the deep trap were much lower, ranging between 0.02 and $0.12 \mathrm{~g} \mathrm{~m}^{-2} \mathrm{~d}^{-1}$ for organic carbon and 0.15 and $0.80 \mathrm{~g} \mathrm{~m}^{-2} \mathrm{~d}^{-1}$ for inorganic carbon.

The overall composition of the collected material did not vary much over the course of the experiment nor between traps on the same mooring. Consequently, individual contents were averaged for the four sites (Table 1). The fluxand time-weighted annual means showed no marked differ 
Table 1

Time- and flux-weighted mean composition (dry weight \%) of downward settling particles collected at the four stations on the sandy plain and the deep slope off the Taotoi Pass

\begin{tabular}{|c|c|c|c|c|}
\hline & Carbonate $(\% \mathrm{dw})$ & Organic matter (\% dw) & Residual fraction (\% dw) & Plants $>1 \mathrm{~mm}(\% \mathrm{dw})$ \\
\hline Sandy plain eastern station & 88.9 & 2.8 & 7.8 & 0.5 \\
\hline Sandy plain pass station & 89.8 & 2.3 & 7.0 & 0.9 \\
\hline Sandy plain western station & 88.5 & 2.3 & 8.3 & 0.9 \\
\hline Deep slope & 89.3 & 2.8 & 6.8 & 1.1 \\
\hline Time- and flux-weighted mean & 89.7 & 2.4 & 7.1 & 0.8 \\
\hline
\end{tabular}

ences between the different sites. Mean carbonate contents, assumed to be in the form of calcium carbonate (inorganic carbon $\% \times 8.33$ ), varied between 88.5 and $89.8 \%$. These results indicate that the bulk of the settling material (close to $90 \%$ ) was represented by calcium carbonate. Mean organic matter (taken as organic carbon $\times 1.8$, Delesalle et al__ 1998) varied between 2.3 and $2.8 \%$. The overall average content in organic matter was $2.4 \%$. Debris of marine and higher plants $>1 \mathrm{~mm}$ also showed little variation between 0.5 and $1.1 \%$ of the total weight. Most of them belonged to the reef system (Sargassum, Turbinaria, Dictyota, Hydroclathrus, Asparagopsis, Padina, Boodlea, Casuarina, Spermaphyte leaves). This biogenic fraction was better represented in front of the pass and downstream, and especially deeper in the slope trap. Finally, the residual fraction (total mass minus the three other components) varied between 6.8 and $8.3 \%$. It represented, on average, $7 \%$ of the total. Microscopic examination showed that it was essentially made of terrigenous and volcanic material, and particularly feldspars that were identified by $\mathrm{X}$-ray diffractometry.

\subsection{Heavy versus light fractions in the trap samples}

Since all samples collected at the three sandy plain sites showed the same trend, we only present the results obtained for the station off the pass axis (Fig. 4). The heavy fraction content of trapped material, i.e. particles with intrinsic settling velocities $>500 \mathrm{~m} \mathrm{~d}^{-1}$, followed the same temporal pattern as total mass flux. For the lowest mass fluxes $\left(<20 \mathrm{~g} \mathrm{~m}^{-2} \mathrm{~d}^{-1}\right)$ the heavy fraction reached a minimum value of $\approx 30 \%$. On the contrary, for higher mass fluxes, the heavy fraction represented more than $60 \%$ of the collected particles, with a maximum value of $\approx 80 \%$. The samples from the deep trap showed a similar evolution, but the heavy fraction content varied within a limited range of $40-65 \%$.

\section{Discussion}

\subsection{Quality check of trap-measured fluxes}

Among the limitations that can affect the ability of sediment traps to provide actual estimates of downward particle fluxes, biological contamination and hydrodynamic bias are probably the most important for traps deployed in shallow environments US Gofs, 1989) Before going further into the discussion it is therefore necessary to check the validity of the flux data determined during our experiment. To avoid biological contamination during the rather long deployment periods within these warm waters, i.e. several weeks to 6 months at temperatures from 20 to $29^{\circ} \mathrm{C}$, formalin was chosen for its proven superiority over other preservatives as an effective biocide to kill swimmers and a true preservative to prevent degradation of organic matter. Combined with the careful, exhaustive removal of swimmers under the microscope it can thus be safely assumed that the chemical composition of trapped particles presented here represents true, uncontaminated values.

Regarding the potential hydrodynamic bias, we have to stress first that the two trap designs used were cylindrical in shape and presented aspect ratios of at least 2.5 , respecting thus two empirical rules that proved to be particularly important for trapping efficiency Gardner, 1980a, h; Butman. 1986). Unfortunately no current meters were deployed during the course of this experiment, a situation that precludes any direct check of the effects of the real dynamical conditions experienced by the traps. We have therefore to rely on measurements performed previously in the same area, partly as a feasibility test for the present work. Currents were measured on the sandy plain at $40 \mathrm{~m}$ in depth for a 10-d period in September 1993. Average speed was $10.8 \mathrm{~cm} \mathrm{~s}^{-1}$ and $75 \%$ of all measurements were $<15 \mathrm{~cm} \mathrm{~s}^{-1}$, i.e. below the empirical threshold beyond which trapping efficiency potentially decreases Gardner 1980b: Baker et al. 1988). Hydrodynamic conditions at $440 \mathrm{~m}$ in depth on the slope were further measured on three occasions, for a total of seven months between September 1993 and November 1996. Average speeds varied between 6.2 and $12.6 \mathrm{~cm} \mathrm{~s}^{-1}$ and $70-90 \%$ of all individual measurements were $<15 \mathrm{~cm} \mathrm{~s}^{-1}$. These different results provide, at least, some hints that the traps have worked satisfactorily for most of the time. The last point that we want to mention is more problematic. Indeed, shallow traps can experience resuspension conditions, during periods of strong swells for example, which are able to resuspend sediments at depths down to several tens of metres. This probably happened on several occasions during our study and could have led to an unpredictable overestimation of downward fluxes. We have unfortunately no solution to bypass this problem. The following discussion will therefore be based not on absolute 
flux values but on relative spatial variations, assuming that the three mooring locations on the sandy plain experienced, if any, similar resuspension conditions.

\subsection{Material export through the reef pass}

The annual flux recorded in front of the Taotoi Pass, approximately twice as much as the flux recorded on the eastern side of the pass - i.e. upstream, with respect to the general westward circulation of water masses on the sandy plain - firmly demonstrates that the reef exports, via the pass, significant amounts of particulate material to the ocean. This three-dimensional pattern of mass flux confirms and extends to the yearly scale preliminary short term observations made in the same area (Delesalle et al. 1998) With an average value close to $90 \%$, carbonate represents the bulk of exported material and trapped particles most probably originate from resuspended lagoon sediments. As evidenced earlier by Delesalle et al_(1998) for this area, the organic carbon content is rather low (less than $2 \%$ on average) and falls within the lower range of published values, i.e. 2.1\% (Palau reef, West Pacific; Hata et al. 1998) to more than $10 \%$ (e.g. Great Barrier Reef; Koop and Larkum, 1987. This feature largely relates (i) to the intense mineralisation occurring at the sediment-water interface inside the lagoon Gattuso et al_.1996h) and (ii) to the fact that the high organic content observed elsewhere were related to a strong contribution of benthic algae to the trapped material Hansen et al._1992) Nevertheless, fresh organic material also leaves our system in the form of amorphous material and plant remains essentially originating from the lagoon. They represent only a minor export vector of total mass $(\approx 1 \%)$ but their contribution to organic matter transport is really important $(\approx 20 \%)$.

The main question then concerns the importance of particulate export through the Taotoi Pass with respect to the carbon production rates within the Tiahura reef system. The outflow of lagoon water through the pass can be seen as a spatially well-delimited jet, that enters the outer reef region perpendicularly to the general circulation. The particles carried by this jet form a plume of turbid, milky waters visible all year round. The spreading area of the plume will depend on hydrodynamic conditions that control both the intensity of the jet and its direction. Most of the time the plume is deflected westward and it is thus unlikely that it significantly contributes to distribute settling particles eastward of the pass. Its downstream influence on the sandy plain seems also rather limited, since the trap located approximately $700 \mathrm{~m}$ west of the pass is not strongly affected. Indeed, fluxes there were only occasionally higher than those measured at the upstream station. The seaward extension of the plume is, on the other hand, impossible to define with the data available since we had only one deep collecting station on the slope, at a straight horizontal distance of approximately $1.1 \mathrm{~km} \mathrm{NW}$ from the pass. Fluxes were roughly ten times lower than those found on the sandy plain, but we have no firm evidence that the material collected at $400 \mathrm{~m}$ in depth could be directly related to particulate export through the pass. Therefore, the only conclusion that can be drawn so far is that, on the average, several $\mathrm{g} \mathrm{m}^{-2} \mathrm{~d}^{-1}$ of total mass are definitively lost by the reef ecosystem, essentially in the form of carbonate, in the immediate vicinity of the pass. We will therefore restrict our calculations to the portion of sandy plain delimited by our experimental area, keeping in mind that they will only provide a first order estimate of the lowest bound of export. Doing so is justified by the fact that this part of the sandy plain is likely to be the first zone outside the pass where sediments accumulate, at least temporarily.

We assume that the mean annual flux of $10.8 \mathrm{~g} \mathrm{~m}^{-2} \mathrm{~d}^{-1}$ measured at the upstream, eastern station represents the best estimate of the 'ambient' flux typical of the sandy plain system. It could result either from the transfer of material flowing out of bays or passes located farther to the east (e.g. the Opunohu Bay, Fig. 1), and/or from the local outer reef bioerosion and/or sediment resuspension as mentioned in the preceding section. An 'exported' mass flux to the sandy plain can thus be calculated for each of the three $700 \mathrm{~m}$ (length) $\times 150 \mathrm{~m}$ (width) boxes of our experimental zone centred around each trap by subtracting the mean 'ambient' flux from the total flux measured at the pass and western stations. The total exported flux is therefore 0 for the eastern box, $21.4 \mathrm{~g} \mathrm{~m}^{-2} \mathrm{~d}^{-1}$ for the box off the pass, and $6.4 \mathrm{~g} \mathrm{~m}^{-2} \mathrm{~d}^{-1}$ for the western one. Using the flux-weighted mean concentrations reported in Table 1 and the area of $1.0510^{5} \mathrm{~m}^{2}$ for each box, these estimates lead to a total export of $9.610^{8} \mathrm{~g} \mathrm{CaCO}_{3}$ year $^{-1}$ and $0.1210^{8} \mathrm{~g}$ organic C year ${ }^{-1}$.

Rough estimates of total calcification and net production values for the entire Tiahura reef area drained through the Taotoi Pass can be obtained from values published for the different reef units (barrier and fringing reef, lagoon channel) Gattuso et al. 1996b. 1997: Boucher et al. 1998) and their respective areas (S. Andrefouët, unpublished data). They amount to $16610^{8} \mathrm{~g} \mathrm{CaCO}_{3}$ year $^{-1}$ and $1110^{8} \mathrm{~g} \mathrm{C}^{-}$ year ${ }^{-1}$, respectively. According to our trap-based estimates, annual particulate carbon export through the pass and onto the limited area of the sandy plain considered here could therefore represent $\approx 6 \%$ of the total annual calcification and $\approx 1 \%$ of the net annual production of the Tiahura reef complex. Regarding carbonate export, our estimate closely matches the value published by Hubhard et al (1990) who found that $5 \%$ of the net carbonate production could be exported from the reef in Cane Bay, Virgin Islands. For organic carbon however, our estimate seems particularly low if one considers for example the work of Atkinson and Grigg (1984) who suggest, on the basis of a modelling approach of food webs at French Frigate Shoals, Hawaii, that up to $10 \%$ of the net organic production of the reef could be permanently lost via sediment burial or export to the ocean. Besides the fact that the two systems are morphologically and structurally very different, the one 
order of magnitude difference in the respective estimates of organic carbon loss relative to net production could also result (i) from the different methodological approaches (measurement versus modelling), and (ii) from the fact that trap-measured export only considers settling particles and therefore does not include other potential vectors such as dissolved or suspended matter.

We are of course perfectly aware of the limitations inherent to such first-order calculations. But even if the spreading area is probably larger than the one considered here and the measured trap fluxes eventually underestimated for various reasons (e.g. hydrodynamic bias that leads to trap undersampling; discrete sampling that could have missed some extreme events), our values suggest that only a limited fraction of carbon was exported from the reef ecosystem towards the open ocean. This is especially true for organic carbon, and our estimate would need a severe, unlikely correction to make loss of particulate organic carbon via the pass a significant term in the total carbon budget for the Tiahura reef system.

\subsection{Factors controlling particulate export from the reef ecosystem}

The relationship between the composition of settling particles and total mass flux provides some understanding of the processes that control particle export through the pass. Indeed, organic and inorganic carbon concentrations in settling particles correlated well with total mass flux (Fig. 5), at least for the shallow traps (for the deep trap at $400 \mathrm{~m}$, no clear relation was found). A negative correlation was found for organic carbon content of sandy plain particles, and a positive correlation for inorganic carbon. Thus, during periods of increased export, the material is enriched in carbonate but impoverished in organic matter.
The decrease in organic carbon content with increased mass flux has been mentioned earlier for temperate margin environments (Buscail et al. 1990; Heussner et al. 1999) It was recognised as resulting from a dilution process of organic carbon by terrigenous material directly related to river inputs or surficial sediment resuspension. In our case, inorganic carbon substitutes for the terrigenous fraction, because of the carbonate nature of the reef lagoon that provides the bulk of exported material.

High flux periods were further characterised by particulate material with a significant enrichment in the heavy fraction (Fig. 4). This suggests that the quantity and the quality of the material exported to the sandy plain largely depends on dynamic processes. Indeed, the predominant role of hydrodynamics as a controlling factor of reef environments has already been stressed by several authors Bradbury and Young. 1981: Wolanski et al.. 1994: Larcombe, 1995. We therefore suspect that the intensity and direction of waves and swells could control the spatial and temporal variations of particle fluxes on the sandy plain, and hence of carbon export from the reef ecosystem. In French Polynesia, swell directions present a marked seasonal signal as it can be seen from observations made during the course of our experiment (Fig. 6). Waves and swells directly influence hydrodynamic conditions within the lagoon Lenhardt_1988) During the summer season (October to April) northern swells and northern winds predominate. They hit the front of the reef directly on the northern coast of Moorea. Large quantities of water enter the lagoon over the reef crest, a process that decreases the residence time of lagoon waters and leads to a high outflow through the pass Lenhardt_1988) The shallow lagoon waters $(\approx 2 \mathrm{~m}$ in depth) present an increased turbidity provoked by resuspension of fine and coarse surficial sediments. When expelled from the lagoon, these turbid waters generate the increased

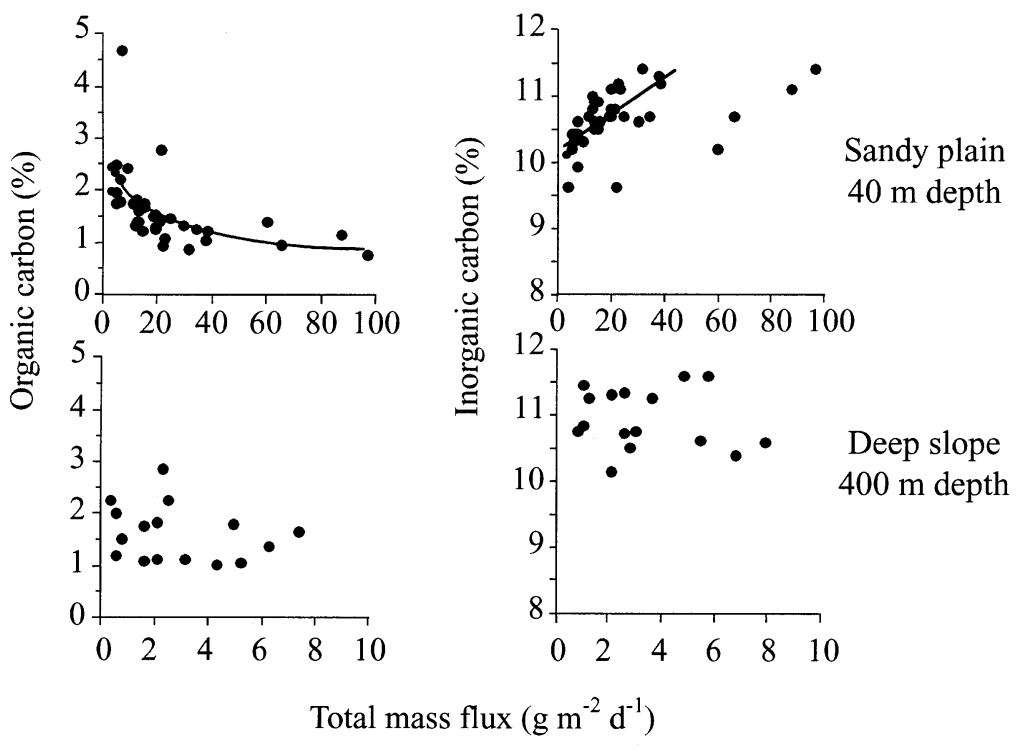

Fig. 5. Organic and inorganic carbon concentrations of settling particles as a function of total mass flux. Results from all traps on the sandy plain have been merged. 


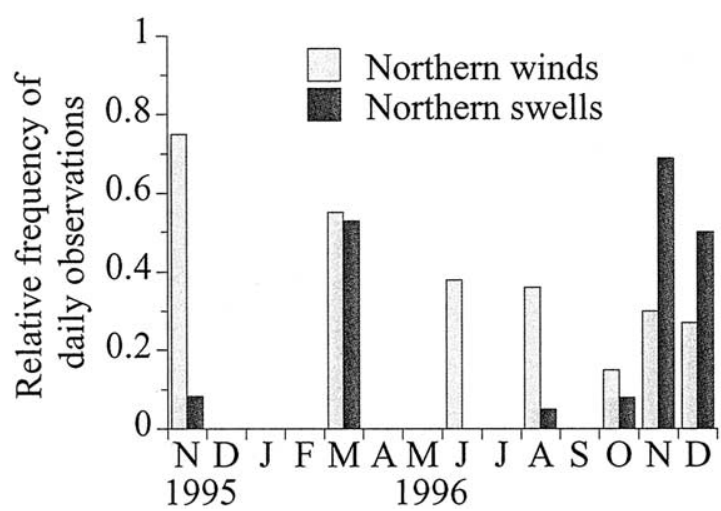

Fig. 6. Variation of northern swell and wind frequencies during the sampling period (November 95-December 1996).

fluxes of settling particles observed during this period off the pass, and occasionally downstream. During winter (April to October) swells and winds mainly originate from the southern sector. Although they are more energetic, they have less impact on the protected north-west reef system that was studied here. The amount of water flowing over the reef is lower, the residence time increases, and lagoon water masses are less agitated and turbid. Smaller amounts of material are thus exported, and the fine (light), organic-rich material predominates. However, exceptional short-term events like strong winds or swells sometimes temporarily disrupt this general seasonal trend. In particular, cyclones are able to modify the reef geomorphology Scoffin, 1993. Harmelin-Vivien.1994 In such cases of exceptional meteorological conditions, and whatever the swell direction, the whole reef system is under the influence of strong hydrodynamic conditions that will entrain the export of large amounts of material.

Mechanisms controlling particle transfer in the Moorea reef therefore appear to be largely dynamical. Since such processes are related to weather conditions and climate, carbon export processes from the reef system towards the open ocean could be ultimately controlled by the variability of climatic factors.

\section{Acknowledgements}

We are indebted to Michel Pichon for his constructive comments on the various drafts of this manuscript. Special thanks are due to Nicole Delsaut and Bruno Charrière for their daily help in the laboratory, and to Jacques Carbonne, James Algret, and Yannick Chancerelle for their technical help in the field and at Criobe. We also thank Thierry Courp for the preliminary work on X-ray diffractometry of trap particles, and Bruno Delesalle, co-ordinator of the Emir program. Identification of algae and marine plants was done with the help of Claude Payri. We are also greatly indebted to Serge Andrefouët who recalculated the surface areas of the various Tiahura reef units for this work. This work is a contribution to the Programme national récifs coralliens.

\section{References}

Atkinson, M.J., Grigg, R.W., 1984. Model of a coral reef ecosystem. II. Gross and net benthic primary production at French Frigate Shoals, Hawaï. Coral Reefs 3, 13-22.

Andrews, J.C., Gentien, P., 1982. Upwelling as a source of nutrients for the Great Barrier Reef Ecosystems : a solution to Darwin's question? Mar. Ecol. Prog. Ser. 8, 257-269.

Arias-Gonzalez, J.E., 1994. Bilan trophique d'un écosystème récifal (Tiahura, Moorea, Polynésie française). C.R. Acad. Sci., Paris 317, 1143-1150.

Baker, E.T., Milburn, H.B., Tennant, D.A., 1988. Field assessment of sediment trap efficiency under varying flow conditions. J. Mar. Res. 46, 573-592.

Basillais, E., 1998. Functional role of the fractal morphology of corals: a full model of the nutrient turbulent diffusion fluxes to a coral reef. C.R. Acad. Sci., Paris Série III 32, 295-298.

Biscaye, P.E., Anderson, R.F., Deck, B.L., 1988. Fluxes of particles and constituents to the eastern United States continental slope and rise: SEEP-I. Cont. Shelf Res. 8, 855-904.

Boucher, G., Clavier, J., Hily, C., Gattuso, J.P., 1998. Contribution of soft-bottoms to the community metabolism (primary production and calcification) of a barrier reef flat (Moorea, French Polynesia). J. Exp. Mar. Biol. Ecol. 225, 269-283.

Bradbury, R.H., Young, G.P.C., 1981. The effect of a major forcing function wave energy on a coral reef ecosystem. Mar. Ecol. Prog. Ser. $5,229-241$.

Butman, C.A., 1986. Sediment trap biases in turbulent flows: results from a laboratory flume experiment. J. Mar. Res. 44, 645-693.

Buscail, R., Pocklington, R., Daumas, R., Guidi, L., 1990. Fluxes and budget of organic matter in the benthic boundary layer over the northwest Mediterranean margin. Cont. Shelf Res. 10 (9-11), 1022-1089.

Cauwet, G., 1975. Optimisation d'une technique de dosage du carbone organique des sédiments. Chem. Geol. 16, 59-63.

Crossland, C.J., Hatcher, B.G., Smith, S.V., 1991. Role of coral reefs in global ocean production. Coral Reefs 64, 10-55.

Delesalle, B., Buscail, R., Carbonne, J., Courp, T., Dufour, V., Heussner, S., Monaco, A., Schrimm, M., 1998. Direct measurements of carbon and carbonate export from a coral reef ecosystem (Moorea Island, French Polynesia). Coral Reefs 17, 121-132.

Gardner, W.D., 1980a. Sediment trap dynamics and calibration : a laboratory evaluation. J. Mar. Res. 38, 17-39.

Gardner, W.D., 1980b. Field assessment of sediment traps. J. Mar. Res. 38, $41-52$.

Gattuso, J.P., Frankignoulle, M., Smith, S.V., Ware, J.R., Wollast, R., 1996a. Coral Reefs and Carbon Dioxide. Science 271, 1298-1300.

Gattuso, J.P., Pichon, M., Delesalle, B., Canon, C., Frankignoulle, M., 1996b. Carbon fluxes in a coral reef. I. Lagrangian measurment of community metabolism and resulting air-sea $\mathrm{CO}_{2}$ desequilibrium. Mar. Ecol. Prog. Ser. 145, 109-121.

Gattuso, J.P., Payri, P., Pichon, M., Delesalle, B., Frankignoulle, M., 1997. Primary production, calcification, and air-sea $\mathrm{CO}_{2}$ fluxes of a macroalgal-dominated coral reef community (Moorea, French Polynesia). J. Phycol. 33, 729-738.

Hansen, J.A., Klumpp, D.W., Alongi, D.M., Dayton, P.K., Riddle, M.J., 1992. Detrital pathways in a coral reef lagoon. Mar. Biol. 113, 363-372.

Harmelin-Vivien, M.L., 1994. The effects of storms and cyclones on coral reefs. J. Coast. Res. Special Issue: Coastal Hazards 12, 211-231.

Hata, H., Suzuki, A., Maruyama, T., Kurano, N., Miyachi, S., Ikeda, T., Kayanne, H., 1998. Carbon flux by suspended and sinking particles around the barrier reef of Palau, western Pacific. Limnol. Oceanogr. 43 (8), 1883-1893.

Hatcher, B.G., 1990. Coral reef primary productivity: a hierarchy of pattern and process. Trends Ecol. Evol. 5 (5), 149-155. 
Hatcher, B.G., Imberger, J., Smith, S.V., 1987. Scaling analysis of coral reef systems: an approach to problems of scale. Coral Reefs 5, $171-181$.

Heussner, S., Ratti, C., Carbonne, J., 1990. The PPS3 time-series sediment trap and the trap sample processing techniques used during the ECOMARGE experiment. Cont. Shelf Res. 10 (9-11), 943-958.

Heussner, S., Durrieu de Madron, X., Radakovitch, O., Beaufort, L., Biscaye, P.E., Carbonne, J., Delsaut, N., Etcheber, H., Monaco, A., 1999. Spatial and temporal patterns of downward particle fluxes on the continental slope of the bay of Biscay (northeastern Atlantic). Deep-Sea Res II 46, 2101-2146.

Hubbard, D.K., Miller, A.I., Scatturo, D., 1990. Production and cycling of calcium carbonate in a shelf-edge reef system (Ste Croix, U.S. Virgin Islands): application to the nature of reef systems in the fossil record. J. Sed. Petrol. 60, 335-336.

Kinsey, D.W., 1985. Metabolism, calcification, and carbon production. I. System level studies. Proc. 5th Int. Coral Reef Symp. 4, 505-526.

Koop, K., Larkum, A.W.D., 1987. Deposition of organic material in a coral reef lagoon, One Tree Island, Great Barrier Reef. Estuar. Coast. Shelf Sci. 25, 1-9.

Larcombe, P., Ridd, P.V., Prytz, A., Wilson, B., 1995. Factors controlling suspended sediment on inner-shelf coral reefs, Townsville, Australia. Coral Reef 14, 163-171.

Lenhardt, X., 1988. Hydrodynamique des lagons d'atoll et d'île haute en Polynésie française. Thèse de Doctorat, Museum National d'Histoire Naturelle, Paris.

Odum, H.T., Odum, E.P., 1955. Trophic structure and productivity of a windward coral reef community on Eniwetok atoll. Ecol. Monogr. 25 (3), 291-320.

Pichon, M., 1996. Coral Reef metabolism in the Indo-Pacific: the broader picture. Proc. 8th Int. Coral Reef Symp. 1, 977-980.
Pichon, M., 1997. Interaction between coastal zones, coral reefs and open ocean. 3rd LOICZ Open Science Meeting. LOICZ Meeting Report No. 29,86 .

Qasim, S.Z., Sankaranarayanan, V.N., 1970. Production of particulate organic matter by the reef on Kavaratti Atoll (Laccadives). Limnol. Oceanogr. 2, 281-286.

Rougerie, F., Wauthy, B., 1986. Le concept d'endo-upwelling dans le fonctionnement des atolls-oasis. Oceanol. Acta 9 (2), 133-148.

Sabine, C.L., Mackenzie, F.T., 1995. Bank derived carbonate sediment transport and dissolution in the Hawaïan Archipelago. Aquat. Geochem. 1, 189-230.

Sargent, M.C., Austin, T.S., 1949. Organic productivity of an atoll. Trans. Am. Geophys. Union 30, 245-249.

Scoffin, T.P., 1993. The geological effects of hurricanes on coral reefs and the interpretation of storm deposits. Coral Reefs 12, 203-221.

Smith, S.V., Jokiel, P.L., 1978. Water composition and biogeochemical gradients in the Canton Atoll lagoon. Atoll Res. Bull. 221, 15-53.

Smith, S.V., Jokiel, P.L., Key, G.S., 1978. Biogeochemical budgets of coral reef ecosystems. Atoll Res. Bull. 220, 1-11.

Sournia, A., 1977. Analyse et bilan de la production primaire dans les récifs coralliens. Ann. Inst. Océanogr. 53 (1), 47-74.

Taguchi, S., 1982. Sedimentation of newly produced particulate organic matter in a subtropical inlet, Kaneohe Bay, Hawaï. Estuar. Coast. Shelf Sci. 14, 533-544.

US GOFS, 1989. Sediment trap technology and sampling. Report of the US GOFS Working Group on sediment trap technology and sampling. In: Knauer, G., Asper, V (Eds.), Planning Report Number 10, US GOFS Planning Office, Woods Hole, MA. pp. 94.

Wolanski, E., Delesalle, B., Gibbs, R., 1994. Carbonate mud in Mataiva atoll, French Polynesia: suspension and export. Mar. Pol. Bull. 29 (1-3), 36-41. 